\title{
Five Years Experience of Tracheostomy at a Tertiary Level Hospital (Dhaka Medical College Hospital) In Bangladesh: Review of 257 Cases
}

${ }^{1}$ Mostafa Kamal Arefin, FCPS, MCPS, Otolaryngologist, Department of ENT \& Head Neck Surgery, Dhaka Medical College Hospital

${ }^{2}$ Md. Abdul Quddus Shohag, MS, Otolaryngologist, Department of ENT \& Head Neck Surgery, Sarkari Karmachari Hospital

${ }^{3}$ Satinath Chandra Sarker, FCPS, Otolaryngologist, Department of ENT \& Head Neck Surgery, Dhaka Medical College hospital

${ }^{4}$ AKM Ferdous Rahman, Assistant Professor, Department of Critical Care Medicine, Dhaka Medical College Hospital

${ }^{5}$ Mohammad Shaharior Arafat, FCPS, MS, MCPS, Assistant Professor, Department of ENT \& Head Neck Surgery,

Dhaka Medical College Hospital

${ }^{6}$ Md. Sazzad Samad, MS, Otolaryngologist, Department of ENT \& Head Neck Surgery, Dhaka Medical College Hospital

${ }^{7}$ Syed Ali Ahasan, FCPS, Otolaryngologist, Department of ENT \& Head Neck Surgery, Dhaka Medical College Hospital

${ }^{8} \mathrm{Md}$. Zahidul Islam, FCPS, MS, MCPS, Assistant Professor, Department of ENT \& Head Neck Surgery,

Satkhira Medical College Hospital

${ }^{9}$ Dipankar lodh, FCPS, MCPS, DLO, Associate Professor, Department of ENT \& Head Neck Surgery, Sir Salimullah Medical College \& Mitford Hospital

${ }^{10}$ Sk. Nurul Fattah Rumi, Professor \& Head, Department of ENT \& Head Neck Surgery, Dhaka Medical College Hospital

Abstract:-

\section{Background}

Tracheostomy is a life saving and important surgical procedure throughout the world from long since. Minimum number of study were conducted on tracheostomy in our setting. Based on number, probably Dhaka Medical College Hospital is one of the top institute in the world, where highest number of tracheostomy is being operated (3-10 per day). So, our purpose of this study is to describe our own experiences, regarding indication, complication, decanulation, morbidity and mortality following tracheostomy and to compare the results with the institutes of other countries of the world.

\section{$>$ Methods}

It is a prospective observational study, conducted at Dhaka Medical College Hospital from July 2014 to June 2019. Data were collected from the Registers of emergency and elective operation theatre, indoor, intensive care unit (ICU) and medical record room (where file of all patients are being kept for long time). SPSS software was used for data processing and analysis. Prior to the study ethical approval was obtained from Ethical review committee.

\section{$>$ Results}

Total 257 patients were selected for the study. Among them 210 (81.71\%) were male and 47 (18.29\%) were female. Most of the patients were elderly, above sixty years. Commonest indication for tracheostomy were upper airway obstruction due to laryngeal or other head neck cancer in $\mathbf{7 0 . 0 4 \%}$ of patients. Next important indication was upper airway obstruction due to trauma in $24.9 \%$ cases. Most of the time $(82.88 \%)$ we had to perform Emergency tracheostomy. Longitudinal or vertical incision was employed in majority of the cases. Complication rate following tracheostomy was $18.68 \%$. Emergency tracheostomy has higher complication rate than elective one. $77.82 \%$ of tracheostomized patients were decannulated successfully. $10.89 \%$ of our patients were died for underlying disease, other co-morbid conditions and old age, not due to tracheostomy or tracheostomy related complications.

\section{Conclusion}

Tracheostomy is still a very important lifesaving surgical procedure in the management of airway. Carcinoma larynx is the commonest indication for tracheostomy in our hospital. Tracheostomy related complications can be minimized by raising awareness to our common people regarding earlier attention for treatment of underlying disease as well as optimal, supervised training and good surgical practice of surgeons and all other care givers.

\section{INTRODUCTION}

Tracheostomy is an ancient surgical procedure in which the trachea is surgically opened in the anterior wall and a stoma is created to facilitate ventilation. It is one of the oldest surgical procedures, which was first described in the first century BC 1, 2, 3, 4, 5 .

It is a lifesaving procedure when operated with a proper indication and good surgical practice 6, 7 . Tracheostomy is a common surgical procedure, operated in ICU on seriously ill patients, requiring prolonged mechanical ventilation. It is becoming more familiar and popular day by day, with the increasing demand for intensive or critical care services. 
For facilitating prolonged airway maintenance and support of ventilation, almost $10 \%$ of these seriously ill patients have to undergo trachecheostomy 8-12. Endotracheal intubation, cricothyroidotomy and percutaneous dilatation tracheostomy are some other methods of airway intervention 13, 14, 25. Relief of upper airway obstruction, prolonged mechanical ventilation, airway protection of the unconscious and tracheobronchial toileting are the common indications 14-16. With time being, the indications and overall outcomes of tracheostomy are getting changed (, especially in children).13, 14, 17-20. Few decades back, upper airway obstruction due to inflammatory infection i.e. acute laryngotracheobronchitis, acute epiglottitis etc, was the most common indication for tracheostomy 19-21.

But, now a days neoplasm of the upper respiratory tract i.e. larynx and other head neck region, is the most common indication 16, 20, 22, 23 . This is due to the changing epidemiological pattern and updated knowledge of communicable and non-communicable diseases as well as advancement of medical science. Proper diagnosis, availability and rational use of steroids, antibiotics and timely intervention changes the total scenario 13, 14, 19, 20.

In paediatric population, tracheostomy differs in some extent from the adults. Surgeon has to face more challenges and technical difficulties. So morbidity and mortality rate is relatively more in children 17,18,22,24. Numerous complications can be happened during and following tracheostomy 25, 26. Emergency tracheostomy has higher complication rate compared to elective tracheostomy 26-28. It is reported in literature that, complication rates following tracheostomy ranges from 6 to 66 percent. Less than 2 percent is the average mortality rate in most of the study $26-$ 36.

Optimal, supervised training to the surgeon and all other health care professionals regarding surgery and postoperative care, can minimize the morbidity and mortality following tracheostomy. 32, 37. Minimum number of study were conducted on tracheostomy in our setting.

Based on number, probably Dhaka Medical College Hospital is one of the top institute in the world, where highest number of tracheostomy is being operated (3-10 per day). So, our purpose of this study is to describe our own experiences, regarding indication, complication, decannulation, morbidity and mortality following tracheostomy and to compare the results with the institutes of other countries of the world.

\section{METHODS}

\section{$>$ Study design, setting and subjects}

It is a prospective observational study of 257 patients, who underwent tracheostomy, between July 2014 to June 2019 at Dhaka Medical College Hospital (DMCH), a tertiary level of hospital. DMCH is the most prestigious teaching hospital in Bangladesh, having a bed capacity of 2600.
Here, the exclusion criteria was -patients, lacking sufficient information. Data were collected from the Registers of emergency and elective operation theatre, indoor, intensive care unit (ICU), medical record room (where file of all patients are kept for long time) and author's(chief) personal register. A preformed questionnaire was used for entry of this data prior to analysis. The preformed questionnaire included- age, sex, initial diagnosis, indication for tracheostomy, technique of surgery, type of incision, required time before decannulation, duration of hospital stay and complications.

Based on aetiology the initial diagnosis was classified into congenital, trauma, inflammation or infection, neoplasm and others. Upper respiratory tract obstruction, respiratory insuffiency, associated with some other head -neck cancer surgeries and bronchial toileting- these are the indications of tracheostomy grossly.

Complications of tracheostomy were divided in three types, i.e. immediate post-operative period $(<24$ hours of surgery), early post-operative period (i.e. 24 hours $-<7$ days of sugery) and late post-operative ( $>7$ days of surgery). Tracheostomy can be classified according to the urgency ,i.e. emergency tracheostomy and elective tracheostomy. Both can be done under local or general anaesthesia. Usually emergency and bedside tracheostomy were performed under local anaesthesia in Emergency OT or in ICU. Elective tracheostomy were performed in the operation theatre under general anaesthesia commonly. Mostly, longitudinal or vertical incision, otherwise transverse or horizontal incision were given in these 257 cases.

All the procredures (tracheostomy) were performed by the chief author himself with other surgeons (including coauthors), while doctors, trained nurses, ward staffs carried out postoperative tracheostomy care. Electric sucker machine was provided at bed side for suction as per need.

Decannulation of tracheostomies were done, when the airway could be maintained satisfactorily and independently. Observation for at least 6 to 24 hours is needed after decannulation and prior to discharge. To allow healing by secondary intension, required technique was commonly demonstrated to the patients or attendants for applying air tight dressing over the stoma .

Our patients and attendants were instructed adequately (about the timing)- when to bring the patient to the hospital urgently. Patients are advised to come for first follow up (for the first time) one to two weeks later. Next follow ups should be scheduled according to need.

\section{Statistical Analysis}

SPSS software was used for data processing and analysis.

\section{- Ethical Consideration}

Prior to the study ethical approval was acquired from Ethical review committee of Dhaka Medical College Hospital. 
ISSN No:-2456-2165

\section{RESULTS}

\begin{tabular}{|c|c|c|}
\hline Age & Frequency & Percentage \\
\hline $0-10$ & 19 & 7.39 \\
\hline $11-20$ & 8 & 3.11 \\
\hline $21-30$ & 20 & 7.78 \\
\hline $31-40$ & 10 & 3.89 \\
\hline $41-50$ & 7 & 2.72 \\
\hline $51-60$ & 51 & 20 \\
\hline $61-70$ & 141 & 54.86 \\
\hline $71-80$ & 1 & 0.39 \\
\hline Total & 257 & 100 \\
\hline
\end{tabular}

Table-1:- Age Distribution

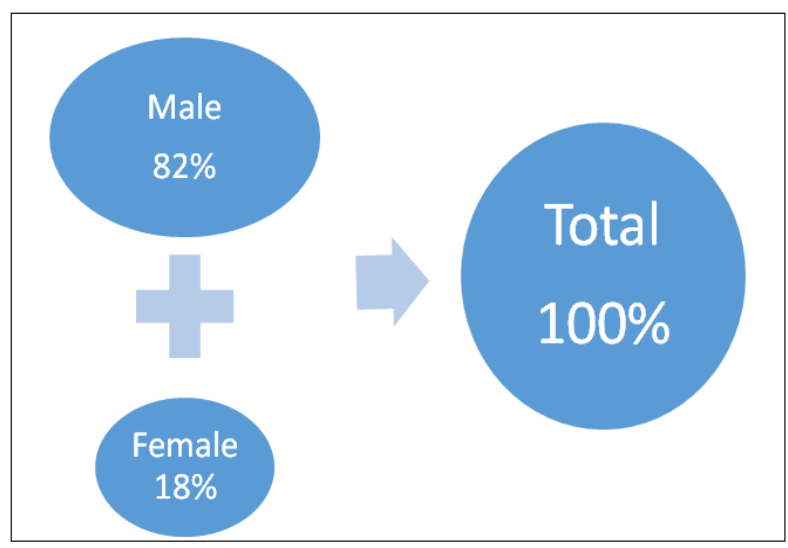

Fig 1:- Sex Distribution

\begin{tabular}{|c|c|c|}
\hline $\begin{array}{c}\text { Type of } \\
\text { tracheostomy }\end{array}$ & $\begin{array}{c}\text { Frequency } \\
\text { ( No. of cases) }\end{array}$ & Percentage (\%) \\
\hline Emergency & 213 & 82.88 \\
\hline Elective & 44 & 17.12 \\
\hline Total & 257 & 100 \\
\hline
\end{tabular}

Table-2: Types of tracheostomy ( Emergency vs Elective)

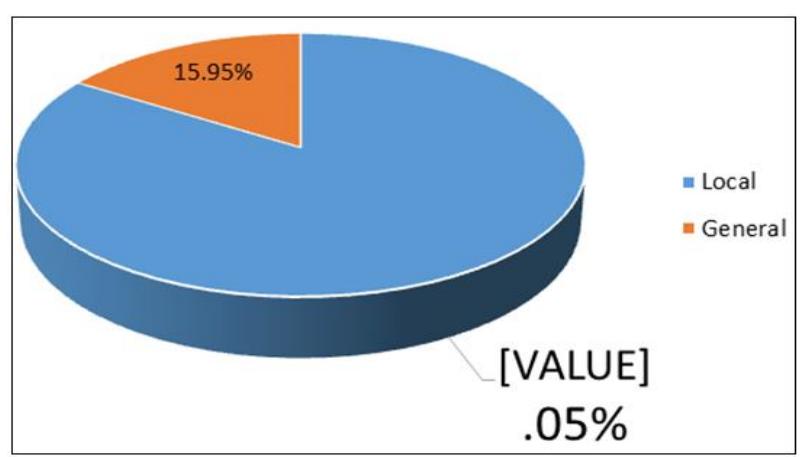

Fig 2:- Type of Anaesthesia (given) in tracheostomy

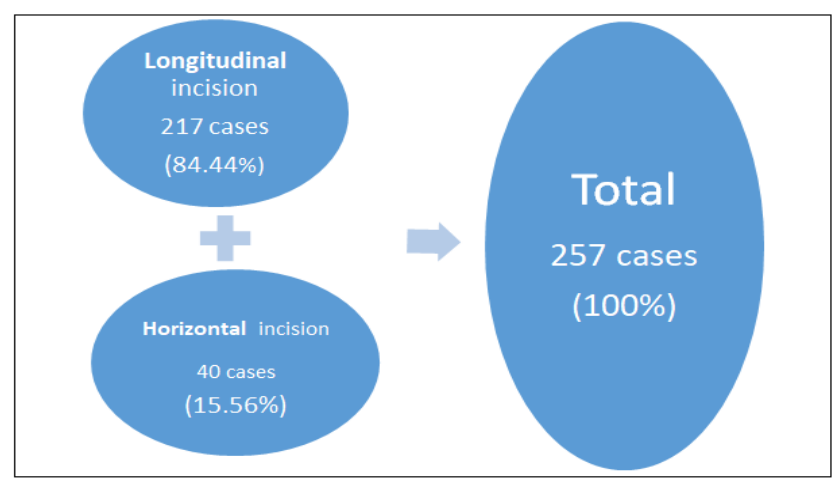

Fig-3: Types of Incision ( Longitudinal vs Horizontal)

\begin{tabular}{|c|c|c|c|}
\hline Indication & Pathological causes & Frequency & Percentage \\
\hline \multirow[t]{4}{*}{ Upper airway obstruction } & $\begin{array}{l}\text { Traumatic- } \\
\text { - Severe head injuries } \\
\text { - Foreign body aspiration } \\
\text { - Severe maxilla facial injuries } \\
\text { - Cut throat, penetrating injury in neck }\end{array}$ & $\begin{array}{c}28 \\
3 \\
4 \\
5 \\
16\end{array}$ & 10.90 \\
\hline & $\begin{array}{l}\text { Neoplastic- } \\
\text { - Laryngeal tumours } \\
\text { - Thyroid tumours } \\
\text { - Other neck tumours }\end{array}$ & $\begin{array}{l}180 \\
155 \\
15 \\
10 \\
\end{array}$ & 70.03 \\
\hline & $\begin{array}{l}\text { Infections- } \\
\text { - Ludwig's Angina } \\
\text { - Retropharyngeal abscess } \\
\text { - Respiratory pappilomatosis } \\
\end{array}$ & $\begin{array}{l}8 \\
4 \\
1 \\
3 \\
\end{array}$ & 3.11 \\
\hline & $\begin{array}{l}\text { Congenital lesions- } \\
\text { Laryngeal web }\end{array}$ & $\begin{array}{l}1 \\
1 \\
\end{array}$ & $\begin{array}{c}.39 \\
84.43\end{array}$ \\
\hline Mechanical ventilator support/ tracheobronchial toileting & Prolonged ventilation & 23 & 8.95 \\
\hline Adjunct to head \& neck surgeries & Anticipated & 7 & 2.72 \\
\hline Others & $\begin{array}{l}\text { Post thyroidectomy tracheomalacia } \\
\text { GBS } \\
\text { Failed endotracheal intubation }\end{array}$ & $\begin{array}{l}4 \\
3 \\
3\end{array}$ & 3.89 \\
\hline
\end{tabular}

Table 3:- Indications of Tracheostomy 
ISSN No:-2456-2165

\begin{tabular}{|c|c|c|}
\hline Type of Tracheostomy & Frequency & Percentage \\
\hline Temporary & 192 & 74.71 \\
\hline Permanent & 65 & 25.29 \\
\hline Total & 257 & 100 \\
\hline
\end{tabular}

Table 4:- Temporary Vs Permanent tracheostomy

\begin{tabular}{|c|c|c|c|}
\hline Period & Complication & Frequency & Percentage \\
\hline Intraoperative & Haemorrhage & 3 & 6.25 \\
& Apnoea & 1 & 2.08 \\
& Injury to local structure & 1 & 2.08 \\
\hline Immediate & Haemorrhage & 3 & 6.17 \\
& Surgical emphysema & 4 & 16.33 \\
& Aspiration pneumonia & 8 & 6.25 \\
& Tube obstruction & 3 & 10.42 \\
& Tube displacement & 5 & 13 \\
& Suprastomal granulation tissue & 5 & 10.42 \\
\hline
\end{tabular}

Table 5:- Complications of Tracheostomy

\section{Demographic profile}

257 tracheostomized patients were included within the study period. $210(81.71 \%)$ patients were male and females were $47(18.29 \%)$. Here male to female ratio is $4.47: 1$. Selected patients age were within 1 to 75 years. In this study, the median age is 45 years and the mean age is $47.5+/-12.48$ years respectively. The majority of patients were in the $6^{\text {th }}$ decade of life $(46 \%)$.

\section{> Timing and indications of tracheostomy:}

Tracheostomy of 213 patients $(82.88 \%)$ were performed as an emergency while 44 patients $(17.12 \%)$ as elective procedures. Neoplasm, (especially carcinoma larynx) is the most common indication for tracheostomy 180 (70.04\%) cases. Trauma to the larynx or other part of upper airway is the second common cause for tracheostomy 64 $(24.90 \%)$ cases.

Incidence of laryngeal and other head- neck malignancies was higher in $6^{\text {th }}-7^{\text {th }}$ decades of life. Again, incidence of trauma, causing obstruction to upper airway was higher in $3^{\text {rd }}-4^{\text {th }}$ decades of life. Laryngeal papillomatosis is the commonest indication for tracheostomy in first decade of life. Patients, who required tracheostomy due to prolonged ventilation, were tracheostomized within 5 to 52 days of intubation. Here, median of this period is 16 days.

Tracheostomy of the 185 patients $(71.98 \%)$ were performed in the Emergency Operation Theatre (EOT) and rest $72(27.02 \%)$ patients were performed in General Operation Theatre (GOT) and intensive care unit (ICU). Midline longitudinal or vertical incision was made in most (217) of the cases. (84.44\%). Most of the cases, i.e. 216 $(84.05 \%)$ were performed under local anaesthesia and rest $41(15.95 \%)$ cases were performed under general anaesthesia. Among all of the tracheostomized patients, tracheostomy was temporary in 192 patients $(74.71 \%)$ and permanent in 64 patients $(24.9 \%)$.

\section{$>$ Complications of tracheostomy}

Complication following tracheostomy were found in 48 cases (18.68\%) among 257 cases. Complications are divided into several types intraoperative, immediate post operative, early post operative and late postoperative. In this study, intraoperative complications are seen in $5(10.42 \%)$ cases, immediate, early and late post operative complications are seen in $5(10.42 \%), 15(31.2 \%)$ and 23 $(47.92 \%)$ cases respectively. Complication rate following tracheostomy was more in emergency tracheostomy (79\%) than in elective one $(21 \%) \quad(\mathrm{P}<0.001)$. In paediatric population (under 10 years) complication rate was higher than adult.

\section{Outcome of tracheostomy}

Primary pathology determines the duration of temporary tracheostomy. In this study this duration ranged from 5 days to 35 months, where the median duration is 3 months. $200(77.82 \%)$ cases, who survived, were decannulated successfully. $132(66 \%)$ cases went home following decannulation, and rest 68 (34\%) cases went home without decannulation. Within few days in their subsequent follow up visit they were decannulated successfully in the ward.

As a part of curative or palliative treatment, tracheostomy of $29(11.28 \%)$ cases was permanent. ICU stay following tracheostomy ranged from 5-33 days, median period was 16 days. Hospital stay following tracheostomy ranged from 4-50 days, median period was 24 days. Due to their underlying diseases $28(10.89 \%)$ patients of this study died. None of their cause of death was tracheostomy or related complication. 


\section{DISCUSSION}

Tracheostomy is one of the oldest surgical procedure in which trachea is surgically opened in it's anterior wall and a stoma is created to facilitate ventilation. The ancient surgical procedure, usually performed in seriously ill patients since first century B.C 1-5(1).

Patients, included in sixth decade of age group had highest incidence of tracheostomy in this study. Tracheostomy was performed more in male than female, and male to female ratio was 4.47:1. Elderly male has more probability of having carcinoma larynx or other head neck malignancy. Some other authors reported similar demographic profile $15,16,20,23$. This result differs with some other studies, regarding age distribution (, where laryngeal trauma is the main cause for performing tracheostomy) $13,14,18,19$.

Tracheostomy has variety of indications. These indications were being changed over several decades 13, 14, 17-20. Previously, infection (e.g. acute laryngotracheobronchitis, epiglottitis), causing upper airway obstruction was the main indication for tracheostomy. But, now a days, better controlling of infections with conservative treatment and the intubation facility in ICU has reduced the need for tracheostomy for the infective conditions 12, 19, 20.

In our series laryngeal carcinoma, causing obstruction of upper respiratory tract, is the most common indication for tracheostomy 15, 16, 19, 20. In other series trauma (, causing upper respiratory tract obstruction) is the most common indication. Head neck neoplasm, especially carcinoma larynx is the next common cause, then prolonged ventilation, foreign body aspirations are the other indications of tracheostomy 13, 14, 45.

In this study, the most common indication in the pediatric group of patient was laryngeal papillomatosis. Several authors have similar result in their study 17, 24, 39. Human papilloma virus transmits from mother to child during delivery. Thus children get laryngeal papillomatosis and the condition deteriorate with time being, causing upper airway obstruction more.

As like as some other studies 14, 16 carcinoma larynx and other head and neck cancer were the main indications for tracheostomy in the 6th-8th decade of life, in this study. Observation of the authors of this study reveals patient of these conditions usually presented in very advanced stage, when airway was severely compromised for the tumor and most of the time with stridor. In majority of cases, tracheostomy was to perform in emergency basis prior to confirmation of the diagnosis. Higher incidence of it indicates laryngeal cancer is increasing in our country day by day alarmingly. To confirm this observation other study is to be conducted.
In this study upper airway obstruction secondary to trauma was the major indication in the 3rd decade of life. Now a days, road traffic accident damaging or injuring structures of head neck region causing severe respiratory distress, is quite common. Especially motorcycle accident is being observed frequently, where popularity of it's increasing day by day due to heavy traffic jam in the capital and after starting of Uber, Pathao etc. apps. Cut throat injury, penetrating injury, hanging, burn and some other violent homicidal attempts cause upper airway obstruction and demanded for emergency tracheostomy. This young group of people are economically active, directly contributes in GDP. High incidence of these injuries indicate their higher activity level and participation in high-risk activities. These traumatic incidences hamper the overall economy of the person, family and country severely 26-32, 34-38, 45.

Vertical (or longitudinal) incision was made most of the time for emergency tracheostomy. We preferred it for having some advantage of saving time. Sometimes, few moments can be the ultimate difference between life and death. With this incision, tracheostomy is easy to perform and chance of bleeding is less. In case of an elective tracheostomy, transverse incision was our preference for better cosmesis, though more time is required 41 .

Overall outcome depends on complications. $18.68 \%$ cases of this study experienced complications, having similarity of the study of Eziyi et al 13. Higher complication rates were observed in some other studies 14, 24, 26, 37, 38. According to Khan et al and Stock et al of different studies, complication rate ranged from 6-66\% 27, 38. Most of the surgeries were performed and assisted in emergency mostly by trainee doctors, having relatively little experiences, causing more complications following tracheostomy. Majority of the patients of our country reached at Hospital in late stage, most of the time with stridor.

Our recommendation is tracheostomy should be performed by an expert surgeon, at least in presence or supervision of an expert or skilled surgeon. To minimize the probable complication, proper facilities, instruments and efficient man power (supporting staffs) are to be ensured.

Complication rates were observed more in emergency tracheostomy in comparison to elective tracheostomy. This result has similarity with the results of the studies of Adoga et al, Asmatullah et al, Chowdhury and Onakoya et al 24, $26,30,37$. This observation has variation with the report of Khan et al, where elective tracheostomy was the most frequently performed procedure and complication rate was much higher $(40.83 \%)$ than this study 38. (Complication rates during or following tracheostomy were more in paediatric age group $17,18,21,22,24,38)$. 
Post tracheostomy complication rate was higher in paediatric patients (10 years or below) than in adults; this result has similarity with other studies $17,18,21,22,24,38$. Because of smaller larynx and trachea, similarity and close proximity to great vessel, tracheostomy is more challenging and more difficult technically.

In this study, hemorrhage, tube occlusion, tube displacement, stomal infection and suprastomal granulation tissue were common complications of tracheostomy, having similarity with the study of Fasunla et al 42 . Meticulous surgical technique and good postoperative care can prevent complications related to tracheostomy.

To prevent suprastomal granulation tissue formation, cricoid cartilage should be spared carefully during surgery. Performing the procedure with standard aseptic precaution, choosing broad spectrum oral or injectable antibiotic prophylactically is essential for controlling of stomal infection .

In case of unconscious patient, endotracheal tube (cuffed) should not be kept longer than a week.In this study, 200 (77.82\%) cases, who survived, were decanulated successfully; the result of which is comparable to the study of Hussain et al 43. Primary pathology determines the optimal duration of temporary tracheostomy (i.e. when to decannulate). After resolving the upper airway blockage, controlling the respiratory secretions and meeting up the demand of mechanical ventilation decannulation could be considered 42, 44.

ICU stay following tracheostomy ranged from 5-33 days, median period was 16 days. In this study, hospital stay following tracheostomy ranged from 4-50 days, median period was 24 days, which is higher in comparison to some other studies 13,14.

For completion of full diagnostic work up, treatment of underlying conditions (i.e. laryngeal or other head neck cancer), as well as postoperative complication, the duration of hospital stay prolonged. Longer waiting time for next or ultimate treatment procedure, like cancer surgery or radiotherapy or chemotherapy patients are bound to stay in hospital. Most of the patients with temporary tracheostomy desire decannulation before their discharge from hospital. Poor socio-economic condition, stigmata, difficulty with phonation, fear of maintenance of tracheostomy tube and wound by care givers are the contributing factors for longer inpatient stay for our patients.

\section{LIMITATIONS}

In this study data was collected from a single Institute and all the surgeries were done by the chief author with his junior or senior colleagues in this tertiary level of hospital. So, the results may not reflect the total scenario of the country. (Information of some of the patients was incomplete, so they were excluded from the study.)

\section{CONCLUSION}

Tracheostomy is still a very important life saving surgical procedure in the management of airway. Carcinoma larynx is the commonest indication for tracheostomy in our hospital. Tracheostomy related complications can be minimised by raising awareness to our common people regarding earlier attention for treatment of underlying disease as well as optimal, supervised training and good surgical practice of surgeons and all other care givers

\section{ACKNOWLEDGEMENTS}

The authors expressed their heartfelt thanks to all the health care professionals, i.e. doctors, nurses, and other staffs of Department of ENT and Head Neck Surgery, Department of Anaesthesiology and Intensive Care Unit, involved in the surgery and postoperative care. Special thanks to the staffs of the Medical record room for their contribution in data collection.

* Authors' contributions:

- Arefin MK planned the study, collected data, did the literature review, edited, wrote the manuscript, submitted the article.

- The manuscript was read thoroughly, edited, coordinated and finally approved by all other authors.

- Authors' information: Arefin MK, FCPS, MCPS, Otolaryngologist, Department of ENT and Head Neck Surgery, Dhaka Medical College Hospital.

\section{REFERENCES}

[1]. Walts PA, Murthy SC, DeCamp MM. Techniques of surgical tracheostomy. Clin Chest Med. 2003;24:413422.

[2]. Pratt LW, Ferlito A, Rinaldo A. Tracheotomy: historical review. Laryngoscope 2008; 118: 15971606.

[3]. Carroll CM, Pahor A. The history of tracheotomy. J Ir Coll Physicians Surg 2001; 30: 237-238.

[4]. Lloyd D. Dorland's Illustrated Medical Dictionary. Philadephia and London. W.B. Saunders Company, 1986.

[5]. Watkinson JC, Gaze MN, Wilson JA. Treatment options : The principles of surgery. In : Stell and Maran's I lead and Neck Surgery. Butterworth Ileinemann. Oxford, 2000. 49-65.

[6]. Ilce Z, Celayir S, Tekard GT, Murat NS, Ercogan E, Yeker D. Tracheostomy in childhood: 20 years experience from a paediatric surgery clinic. Paediatr Int. 2002;44:306.

[7]. Wood DE. Tracheostomy. Chest Surg Clin N Am. 1996;6:749.

[8]. Esteban A, Anzueto A, Alía I, Gordo F, Apezteguía C, Pálizas F, Cide D, Goldwaser R, Soto L, Bugedo G, Rodrigo C, Pimentel J, Raimondi G, Tobin MJ. How is mechanical ventilation employed in the intensive care unit? An international utilization review. Am J Respir Crit Care Med. 2000;161:1450-1458. 
[9]. Frutos-Vivar F, Esteban A, Apezteguía C, Anzueto A, Nightingale P, González M, Soto L, Rodrigo C, Raad J, David CM, Matamis D, D' Empaire G. International Mechanical Ventilation Study Group. Outcome of mechanically ventilated patients who require a tracheostomy. Crit Care Med. 2005;33:290-298.

[10]. Kollef MH, Ahrens TS, Shannon W. Clinical predictors and outcomes for patients requiring tracheostomy in the intensive care unit. Crit Care Med. 1999;27:1714-1720.

[11]. Fischler L, Erhart S, Kleger GR, Frutiger A. Prevalence of tracheostomy in ICU patients. A nationwide survey in Switzerland. Intensive Care Med. 2000;26:1428-1433.

[12]. Oram J \& Bodenham A. In: Intensive care medicine: Annual update 2008. Editor Jean- Louis Vincent. Sect ion viii pp 323. Springer Science+business media inc. New York.

[13]. Eziyi Josephine Adetinuola EJ, Bola AY, Olanrewaju MI, Oyedotun AA, Timothy OO, Alani AS, Adekunle A. Tracheostomy in south western Nigeria: Any change in pattern? J Med Med Sci. 2011;2(7):9971002.

[14]. Amusa YB, Akinipelu VO, Fadiora SO, Agbakwuru EA. Tracheostomy in surgical practice: Experience in a Nigerian Tertiary Hospital. West Afr J Med. 2004;23(1):32-34

[15]. Hashemi SB.MD, Gandomi B.MD, Derakhsandeh V. MD. Endoscopic evaluation of the causes of upper airway obstruction leading to tracheostomy, in south of Iran; The Iranian Journal of Otorhinolaryngology Vol.18, No.43 Spring-2006.

[16]. Bhuiyan M A R, Rashid M S, Kamruzzaman M, Islam M S, Ahmed K. Tracheostomy in head-neck malignancy; Bangladesh Journal of Otorhinolaryngol 2010; 16(2): 120-125

[17]. Alladi A, Rao S, Das K, Charles AR, Cruz AJ. Pediatric tracheostomy: a 13 year experience. Pediatr Surg Int. 2004;20(9):695-8.

[18]. Primuharsa PSH, Wong CY, Hazim MY, Megat Shiraz MA, Goh BS. Pediatric tracheostomy in Hospital University Kebangsaan Malaysia- a changing trend. Med J Malaysia. 2006;61(2):209-13.

[19]. Goldenberg D, Golz A, Netzer A, Joachims HZ. Tracheotomy: changing indications and a review of 1,130 cases. J Otolaryngol 2002; 31: 211-215.

[20]. Talukdar DC , Litu MA. Tracheostomy at a tertiary level hospital in Bangladesh: any change in pattern? $\mathrm{J}$ Dhaka Med Coll. 2016; 25(2) : 67-71

[21]. Parilla C, Scarano E, Guidi ML, Galli J, Paludetti G. Current trends in pediatric tracheostomies. Int $\mathrm{J}$ Pediatr Otorhinolaryngol. 2007;71(10):1563-7.

[22]. Kremer B, Botos-Kremer AI, Eckel HE, Schlorndoff G. Indications, complications and surgical techniques for pediatric tracheostomies. J Pediatr Surg. 2002;37(11):1556-62.

[23]. Rahman S.H., Ahmed K, Khan A.F.M, Ahmed S.U, Hanif M.A., Haroon A.A. Islam M.A. study of tracheostomy in Dhaka medical Collage hospital; Bangladesh Journal of Otorhinolaryngology 2001; 7(2): 34-40.
[24]. Adoga AA, Ma'an ND. Indications and outcome of pediatric tracheostomy: results from a Nigerian tertiary hospital. BMC Surgery. 2010;10:2.

[25]. Hadi A, Ikram M. Upper airway obstruction: Comparison of tracheostomy and endotracheal intubation. PJLO. 1995;11:25.

[26]. Asmatullah, Inayatullah, Rasool G, Billah M. Complication of emergency tracheostomy. J Postgrad Med Inst. 2004;18(2):225-9.

[27]. 41. Stock MC, Woodward CG, Shirpiro BA, Cane FD, Lewis V, Pecaro B. Perioperative complications of elective tracheostomy in critically ill pa tients. Critical Care Medicine. 1986. pp. 861-3.

[28]. Ahmed K, Rahinan M.A., Rahman S.H, Complications of tracheostomy. Bangladesh Journal of otorhinolaryngology 1998 4)1): 3-6.

[29]. Me Clelland RMA, Complications of trachesotomy. British Medical Journal. 1965; 2: 567-9.

[30]. Choudhary AA, Sultana T, Joardar MAH, Tarafdar KH. A comparative study of elective \& emergency Tracheostomy. Bangladesh J Otolaryngology. 2008;14(2): 57-62.

[31]. Waldron J, Padgham ND, Hurley SE. Complications of emergency and elective tracheostomy: a retrospective study of 150 consecutive cases. Ann.royal coll.surg. eng. (1990)vol.72: 218-20.

[32]. Joseph A. Charles L. Trachesotomy: Management, mortality and complications. The American Surgeon 1969; 35(6): 393-6.

[33]. Jackson C. Tracheostomy. Laryngoscope 1909; 19(4):285-90.

[34]. Durbin CG. Early complications of tracheostomy. Respiratory care April 2005; 50(4):511-15.

[35]. Goldenberg D, Ari EG, Golz A, Danino J, Netzer A, Joachims H. Tracheotomy complications: a retrospective study of 1130 cases, Otolaryngol Head Neck Surge 2000; 123(4): 495-500.

[36]. Manzoor T, Rashid D, Haq AU. Complications of Tracheostomy. Pak armed Forces Med. J. 2000; 50:17. 41. Kato I, Uesugi K, Tracheotomy - the horizontal tracheal incision. J Laryngology and Otology. 2008 vol. 104; 322-25.

[37]. Onakoya PA, Nwaorgu OG, Adebusoye LA. Complications of classical tracheostomy and management. Trop Doctor. 2003;33:148-150.

[38]. Khan FA, Ashrafi SK, Iqbal H, Sohail Z, Wadood. Operative complications of tracheostomy. Pak J Surg. 2010;26(4):308-310.

[39]. Adoga AA, Nimkur LT, Adoga AS. Recurrent respiratory papillomatosis in Jos, Nigeria: clinical presentation, management and outcome. East Centr Afri J Surg. 2008;13(2):105-8.

[40]. Okoye BCC. Tracheostomy in Port Harcourt. Nig J Surg Sci. 2000;10:99-102.

[41]. Kato I, Uesugi K, Tracheotomy - the horizontal tracheal incision. J Laryngology and Otology. 2008 vol. 104; 322-25. 
[42]. Fasunla JA, Aliyu A, Nwaorgu OGB, Ijaduola GTA. Tracheostomy Decannulation: Suprastomal Granulation Tissue in Perspective. East Centr Afr J Surg. 2010;15(1):81-85

[43]. Hussain G, Iqbal M, Ali S, Hussain M, Azam F, Zaman J. An experience of 31 tracheostomies performed at Saidu Teaching hospital. Gomal J Med Sci. 2009;7(2):555-9.

[44]. C hristopher KL. Tracheostomy Decannulation. Respir Care. 2005;50(4):538-541.

[45]. Gilyoma JM, Balumuka DD, Chalya PL.Ten-year experiences at a University teaching hospital in Northwestern Tanzania: A retrospective review of 214 cases. World J Emerg Surg.2011;6:38 